\title{
As viagens de Taunay: natureza, civilização e governamentalidade na Província do Paraná
}

\author{
Taunay's voyages: nature, civilization and \\ governmentality in the province of Paraná
}

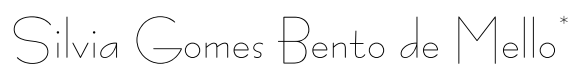

Alfredo d'Escragnolle Taunay ${ }^{1}$ visitava a gruta de Itape$r u c u^{2}$, no municipio de Votuverava,naquele 10 de dezembro de $1885^{3}$. Ele era então presidente do Paraná, província que governou entre 29 de setembro de 1885 e 3 de maio de 1886 . E a localidade em que se encontrava distava aproximadamente seis léguas e meia de Curitiba, cidade sede do governo provincial e onde residia aquele ilustre visitante. Naquela ocasião, a gruta de Itaperuçú - ou daAnta Grande - era de acesso dificil e não tinha fama que atraísse todos os visitantes que a sua beleza

\footnotetext{
* Doutora em História. Professora do Departamento de História da Universidade Estadual do Centro-Oeste - Unicentro, campus Santa Cruz/Guarapuava-PR. E-mail: silvinhamello@ hotmail.com

${ }^{1}$ Alfredo Maria Adriano d'Escragnolle Taunay (1843-1899), o Visconde de Taunay, provinha de uma família de origem francesa ligada às artes: seu pai, Felix-Émile Taunay, e seu avô, Nicolas-Antoine Taunay, foram pintores e professores da Escola de Belas-Artes do Rio de Janeiro. Ele próprio dedicou-se à literatura: Inocência (1872) é o seu romance de maior destaque - embora seja dono de uma obra literária variada, que conta com romances, contos, peças teatrais e narrativas de viagens, militares, históricas, políticas e sociais. Na política, foi um homem de certo destaque nos tempos de D. Pedro II, exercendo mandatos como deputado, senador e presidente das Províncias do Paraná (1885-1886) e de Santa Catarina (1876-1877). Com a Proclamação da República, em novembro de 1889, Alfredo Taunay afasta-se da vida pública. Formou-se em Ciências Físicas e Matemáticas na Escola Militar do Rio de Janeiro (cidade onde nasceu) e atuou como engenheiro. O título nobiliárquico de Visconde recebeu de D. Pedro II, em 6 de setembro de 1889.

${ }^{2}$ De acordo com a grafia da época, Tapirussú. Ao longo deste artigo, optou-se por atualizar as grafias dos vocábulos.

${ }^{3}$ Ver: TAUNAY, Alfredo d'Escragnolle. Curiosidades Naturais da Província do Paraná. Revista do Instituto Histórico e Geográfico Brasileiro. Rio de Janeiro: Tipografia e Encadernação a vapor, 1890, Tomo LIII. Parte I ( $1^{\circ}$ e $2^{\circ}$ trimestres), p.193-241. Texto originalmente lido no Instituto Histórico e Geográfico Brasileiro, em agosto/setembro de 1889, pelo próprio Visconde de Taunay.
} 
mereceria. Taunay estava acompanhado de umas vinte cinco ou trinta pessoas e narrou as dificuldades de locomoção no interior da gruta, onde o solo era irregular, a escuridão dominava e os desniveis de altura exigiam que se locomovessem de cócoras em determinados trechos ${ }^{4}$.

Tudo aquilo poderia fazer a visita à gruta pouco atrativa. No entanto, Taunay maravilhava-se com o que via: as formações de estalagmite e estalactite consistiam em um verdadeiro espetáculo. O gotejamento d'água formava figuras inesperadas e singulares, à espera de um olhar aventureiro pronto para embarcar numa viagem criativa que identificaria naquelas formações seres fantásticos e mitológicos, arquiteturas exóticas e bizarras ou simplesmente um animal, uma construção, um objeto convencional. A natureza oferecia, assim, primorosos trabalhos feitos da matéria-prima mais abundante em Itaperuçú: a água. A umidade que escorria das paredes, as pequenas corredeiras d'água que serpenteavam pelo chão garantiam a mutabilidade das esculturas que se formavam: "tudo [...] em via de continua transformação e mudança", dizia o presidente Taunay. Aliada à alta capacidade da água em se transfigurar em novas imagens, a iluminação das velas, quando aproximada das esculturas, produzia surpreendentes efeitos sobre elas. Era assim que se poderia dizer que, a cada nova visita à gruta, um novo espetáculo era contemplado!

As maravilhas da gruta foram engrossadas na pena do presidente da província, pela transcrição de um trecho de um relato do engenheiro Monteiro Tourinho ${ }^{6}$ a respeito de sua visita à Itaperuçu ${ }^{7}$. Nele, o engenheiro associava as galerias da gruta a movimentos marcantes da arquitetura europeia: surgiam, assim, capelas góticas, salões de castelos medievais e até cú-

\footnotetext{
${ }^{4}$ Ibidem, p. 206-209.

${ }^{5}$ Ibidem, p. 207.

${ }^{6}$ Francisco Antonio Monteiro Tourinho (1833-1885), engenheiro que participou de importantes obras no Paraná, tais como a construção da estrada da Graciosa (Antonina-Curitiba), primeira estrada ligando Curitiba ao porto, construída após a emancipação política da Província e a instalação de colônias militares nas proximidades da foz do rio Iguaçu.

${ }^{7}$ Ver: TAUNAY, op.cit., p. 209-211. Salienta-se que, além da visita de Alfredo Taunay e do engenheiro Monteiro Tourinho à gruta em questão, esta também foi visitada por Adolfo Lamenha Lins, em 1875, quando era presidente do Paraná, juntamente com o engenheiro Luis Parigot.
} 
As viagens de Taunay: natureza, civilização e governamentalidade na província ...

pulas de catedrais renascentistas. O melhor da arte produzida pelo gênio humano no ocidente estava à disposição, naquelas paragens paranaenses, daqueles que fossem capazes de deixar a imaginação correr solta. Assim, Monteiro Tourinho falava de ninfas e monges, de esfinges, fontes misteriosas e monstros diluvianos, além de metamorfosear figuras provenientes das mais variadas tradições: "Dá-se um passo, vê-se um grupo de frades a rezarem; dá-se outro, transformam-se os frades em sátiros; chega-se mais perto e só se vê um incongruente acervo de rochas e toscas saliências tronco-cônicas e cilindricas".

As percepções e descrições do engenheiro Monteiro Tourinho estavam em consonância com o conjunto do relato do presidente Taunay, denominado por ele de Curiosidades Naturais da Província do Paraná. Esse texto construíra um olhar para o Paraná que se caracterizava, em grande medida, por salientar as belezas naturaisda província. Sendo assim, a referência a elementos da cultura europeia, presentes nas anotações de Monteiro Tourinho sobre a gruta do Itaperuçu, denotam que o sentido de beleza não se encerrava nos predicados da natureza, mas estabelecia um trânsito direto com uma estética própria das artes. De fato, a natureza e as artes são matrizes inalienáveis do belo, de modo que não é de se estranhar que estejam associadas ${ }^{9}$. Convém, no entanto, ressaltar que tal associação com a produção artística e cultural europeia, não esteve desassociada de um projeto mais amplo de construção e projeção do que seria o Paraná cujos contornos são estabelecidos no conjunto de escritos de Alfredo Taunay referente ao período em que governou tal provincia ${ }^{10}$.

Associado a tal constituição estética - que enfatizava o que havia de belo no Paraná -, a província se construía na medida em que localidades como a gruta de Itaperuçu ganhavam visibilidade e sentido no Paraná; na medida em que eram apropriadas discursivamente e sobre elas se projetava um propósito

\footnotetext{
${ }^{8}$ Ibidem, p. 211.

${ }^{9}$ Sobre esta questão, ver: OLIVEIRA, João Vicente Ganzarolli de. Insurgência contra o nada. A humanização da arte: temas e controvérsias na filosofia. Rio de Janeiro: Pinakotheke, 2006, p. 67-84.

${ }^{10}$ Trata-se de relatórios de governo, relatos de viagem publicados em revistas, notas em jornais, livro de memórias.
} 
que as inseriam no movimento geral do Paraná, ampliavam-se os contornos e o entendimento que se tinha dessaprovíncia. Assim, a respeito de Itaperuçu, Taunay salienta o interesse de torná-la mais acessivel, uma opção de passeio para quantos visitassem Curitiba:

Se a mão do homem, inteligentemente dirigida, se empenhasse em dar mais alguma comodidade ao ingresso daquela enorme caverna, melhorasse as suas condições internas e fizesse realçar suas muitas belezas [...] [seria] a gruta de Itaperuçu motivo de lindíssimo passeio e digna de ser apreciada por quantos chegassem ao planalto de Curitiba ${ }^{11}$.

Por meio da sua escrita, Taunay confere existência e materialidade a localidades paranaenses pouco conhecidas e de acesso e trânsito não plenamente estabelecidos. Seu olhar, de presidente de Província, buscava constituir um sentido para o Paraná e, para tanto, era preciso expandir horizontes para além de Curitiba; era necessário reconhecer essas novas regiões como integrantes do Paraná - do Paraná moderno que se desejava. O engenheiro Monteiro Tourinho também refere-se à importância de tornar Itaperuçu mais acessivel: "achando-se tão perto de Curitiba, não compreendemos, por que não tem sido com mais frequência visitada esta maravilha do Paraná" ${ }^{2}$. Neste duplo movimento de apropriação - o que institui a gruta como maravilha do Paraná e o que visa integrá-la à vida ativa da província -, uma determinada modernidade se constituía. A respeito desses movimentos e dessa modernidade, tratará as páginas que se seguem.

\section{Alfredo Taunay: um presidente de Província em trânsito pelo Paraná}

Alfredo Taunay sentia-se envaidecido por ter sido o primeiro presidente de Província a se deslocar até Guarapuava, que era então o mais extenso dos municípios paranaenses, ocupando uma área significativa da porção mais ocidental da provincia. Ausentou-se de Curitiba com a finalidade de conhe-

${ }^{11}$ TAUNAY, op.cit., p. 209.

${ }^{12}$ Ibidem, p. 211. 
As viagens de Taunay: natureza, civilização e governamentalidade na província ...

cer Guarapuava entre 29 de março e 16 de abril de 1886, lá permanecendo por três dias. Ao empreender tal viagem, por ele mesmo considerada como um percurso dilatado e incômodo ${ }^{13}$, não lhe escapava a importância política daquele município para o progresso geral do Paraná. As condições de viagens pela província eram dificeis, dada a precária situação das estradas e, de mais a mais, chegar a Guarapuava exigia atravessar a Serra da Esperança, feito que historicamente era visto como um prodígio.

Como resultado da viagem a Guarapuava, Taunay não deixou de ordenar consertos de pontes e reparos em estradas ${ }^{14}$. Do mesmo jeito que fizera na gruta deItaperuçu, o seu olhar atento, de presidente de Província, não queria deixar escapar os melhoramentos que poderiam ser feitos para tornar mais fáceis as comunicações no Paraná. No entanto, tão importante quanto a caracterização do olhar lançado por Taunay para os lugares que conhecia em suas viagens pelo interior da província, é ele tê -las realizado. E o seu esforço em realizá-las não se resume aos dois exemplos citados (a gruta deItaperuçu e Guarapuava), mas se estende a outros deslocamentos, sobretudo, aos Campos Gerais. Nessas viagens, ele passou por pequenas povoações, percorreu lagoas, furnas, quedas d'água e rios e conheceu pessoas de diversas condições sociais e origens étnicas.

A partir do interesse de Taunay de sair da comodidade de Curitiba, onde morava e de onde governava o Paraná, para viajar pela provincia, conhecendo regiões e seus respectivos moradores, contemplando lugares ou inteirando-se do seu desenvolvimento, delineiam-se os traços de uma política de gerência territorial. A experiência de conhecer a vida na provincia - para além do eixo litoral-capital - confere uma identidade muito específica a sua administração. Tratava-se de constituir uma política administrativa em que se alinhasse o conhecimento do território com as possibilidades de se ter um melhor domínio sobre

\footnotetext{
${ }^{13}$ Nas palavras de Taunay: "Lembro-me sempre com desvanecimento que fui o único presidente ou governador, que até hoje se tenha abalado a ir a Guarapuava afrontando os incômodos daquela dilatada viagem". Carta escrita a Luiz Daniel Cleve (jornalista, residente em Guarapuava), datada de 27 de novembro de 1895. Publicada em Guarapuava/1928. 2ed. Curitiba: Empresa Editora Oliveiro, 1928, s/p.

${ }^{14}$ Exposição com que S. Ex. o Sr. Dr. Alfredo D'escragnolle Taunay passou a administração da Província do Paraná ao Exm. Snr. Dr. Joaquim de Almeida Faria Sobrinho a 3 de maio de 1886. Curitiba, p. 70. [Relatório de Governo].
} 
ele, proporcionando uma compreensão tal da vida na província que lhe facultasse fazer as ações necessárias para torná-la mais próspera. Essa mobilidade de Taunay pela província ajudava a configurar um Paraná cuja extensão, grandeza e importância só poderiam ser plenas quando o seu interior não fosse mais uma incógnita. Conhecê-lo era um grande passo a ser dado para desmistificar seus mistérios, tornando-o compreensivel, próximo, dominável: afinal, conhecer o espaço leva irremediavelmente ao seu apequenamento, posto que "nada que pode ser medido pode permanecer imenso" 15 .

A respeito de tal política de viagens, marca indelével de seu governo, Alfredo Taunay esclarece, anos mais tarde, ao escrever suas memórias:

Verdade é que não me poupava à fadiga, em contínuas viagens, para ajuizar das estradas e caminhos, conhecer as localidades, pôr-me em contato com os seus homens e estudar de visu as questões que lhes eram atenuantes.

Nem há melhor sistema de administrar. Mais vale um olhar, uma impressão repentina e segura dos fatos, do que os mais minuciosos e bem elaborados relatórios e exposições ${ }^{16}$.

Era dessa forma que o presidente da Provincia distinguia-se dos seus predecessores e marcava as características que peculiarizaram o seu governo. Sua forma de administrar lhe parecia superior ao governo apenas de gabinete e nos aponta para uma modernidade que se insinuava no Paraná. A necessidade de ver não era uma mera curiosidade - ainda que o homem moderno seja um curioso ${ }^{17}$-, mas caracteriza um modo de lidar e conhecer o meio que tem uma historicidade específica. As viagens movidas pelo desejo de conhecer e explorar novas terras foram um distintivo na modernidade, tão marcada pela ânsia de experimentar o novo. Há um prazer no ato de ver e uma soberania do olhar sobre os outros sentidos. O mundo deveria ser inventariado, ou seja, as suas regiões e povos deveriam ser explicados, decifrados, 'catalogados'. E uma descrição porme-

${ }^{15}$ ARENDT, Hannah. A Vida Activa e a Era Moderna. In: A Condição Humana. 10 ed. Rio de Janeiro: Forense Universitária, 2001, p. 262.

${ }^{16}$ TAUNAY, Alfredo d'Escragnolle. Memórias. São Paulo: Melhoramentos, 1948, p. 430.

${ }^{17}$ Sobre essa questão, ver: HARTOG, François. Memória de Ulisses: narrativa sobre a fronteira na Grécia antiga. Belo Horizonte: UFMG, 2004. 
As viagens de Taunay: natureza, civilização e governamentalidade na província ...

norizada só poderia vir de observações feitas com minúcia. Por isso, não foi à toa a importância adquirida pelas experiências in loco nesse momento: fez-se urgente sair dos gabinetes e dos grandes centros para conhecer, observar e experimentar os lugares distantes, desconhecidos e exóticos. As viagens de Taunay pelo Paraná não estavam desvinculadas dessa lógica: ele era um observador em trânsito pela província, alguém que fazia da sua mobilidade a resposta à exigência moderna de conhecer o mundo.

Evidentemente, o olhar desse presidente que transitava pela provincia se constituiu por meio de um conjunto de experiências que extrapolam o período em que governou o Paraná e que fizeram do seu olhar, um olhar cheio de civilização. Afinal, "é evidente que o próprio ato de identificar o local pressupõe nossa presença e, conosco, toda a pesada bagagem cultural que carregamos"18. Em se tratando de Taunay, é preciso considerar sua vivência na realidade europeia (onde estudara entre 1878 e 1880) e carioca (nasceu e viveu boa parte da vida no Rio de Janeiro $)^{19}$, ainda que seu olhar também já tivesse demonstrado sensibilidade para a vida no sertão, para a vida que escapava ao ambiente civilizado ao qual estava habituado. Sua estada em MatoGrosso, por ocasião da Guerra do Paraguai, marcara-lhe o espírito e inspirara alguns escritos, como Inocência (1872), seu mais famoso romance. Acrescenta-se que ele acumulara um razoável número de experiências de viagens, tanto no Brasil (normalmente levado pelas suas próprias atividades profissionais), quanto no exterior ${ }^{20}$. Tal diversidade de experiências e de referências a pessoas, lugares, natureza e civilização, certamente condicionou e particularizou seu olharpara o Paraná.

Seu fácil trato com as palavras também reverberou no registro de suas viagens pelo Paraná. Enquanto leitor e, principalmente, como escritor, Taunay tinha os recursos necessários

\footnotetext{
${ }^{18}$ SCHAMA, Simon. Paisagem e Memória. São Paulo: Companhia das Letras, 1996, p 17.

${ }^{19}$ A respeito de tais vivências, salienta-se o fato de vir de uma família de artistas, sua formação em ciências físicas e matemáticas, sua atuação como engenheiro, sua carreira na política e nas letras, além das experiências de viagem.

${ }^{20}$ A respeito da biografia de Alfredo Taunay, ver: TAUNAY, op.cit.; OLIVEIRA, Alberto de; JOBIM, Jorge. Visconde de Taunay por Alberto de Oliveira e Jorge Jobim. Rio de Janeiro: Livraria Garnier, 1922. [Coleção Áurea: páginas escolhidas dos maiores escritores].
} 
para registrar suas percepções de viagem. Assim, ao retornar de suas digressões pela província, atribuía sentido à sua experiência por intermédio de relatos de viagens. No próprio curso das viagens, enviava telegramas para jornais da Corte e para o curitibano Gazeta Paranaense informando as novidades e os melhoramentos que faria na província (alguns já solicitados ao tesouro provincial em telegrama próprio): conserto de pontes, instalação de barreiras nas estradas para cobrança de impostos, fundação de sociedades de imigração ${ }^{21}$. A viagem poderia ser também objeto de palestra, como foi o caso de sua visita a Guarapuava, contada, alguns meses depois de seu retorno, no Instituto Histórico e Geográfico do Paraná ${ }^{22}$. Tais divulgações aproximam da capital - de onde era gerida a província - as localidades distantes, mesmo se considerarmos que apenas uma pequena parcela dos curitibanos tinha acesso a tais relatos.

O intuito de realizar tais escritos e conferências, Taunay explica, anos mais tarde, em seu livro de memórias: "Itratava-se de] como o semeador do Evangelho, [sair] atirando ao vento ideias e mais ideias, caíssem ou não na rocha estéril ou na terra fecunda"23. Nesse sentido, a disseminação das suas percepções de viagens fazia parte da sua política de governo. Tão importante quanto viajar, era produzir significado sobre o que vira. Assim, finda a viagem, Taunay poderia encerrar-se em um gabi-

\footnotetext{
${ }^{21}$ Em Curitiba, a Gazeta Paranaense (que defendia os interesses do Partido Conservador, ao qual pertencia Alfredo Taunay) e o Dezenove de Dezembro (que defendia os interesses do Partido Liberal e fazia oposição ao governo de Taunay) registraram notícias da viagem do presidente da Província a Guarapuava, em edições de abril de 1886. O Dezenove de Dezembro costumava ser severo nas críticas às constantes viagens do presidente, questionando o sentido das suas frequentes ausências da capital: "poupe-nos o ilustrado viajante à leitura das longas descrições, dos suculentos almoços e opíparos jantares, que lhe foram ministrados nessa longa digressão; das estrondosas recepções, dos foguetórios, dos arcos festivais, musicais e bailes, com que foi honrado. Dispensamos também, de boa mente, a notícia das numerosas inaugurações, de que já nos deu conhecimento a folha oficial". Dezenove de Dezembro. Curitiba, quarta-feira, 18 de abril de 1896. Ano XXXII, n. 83, p. 01. Em contrapartida, a Gazeta Paranaense remarcava os efeitos positivos da viagem a Guarapuava: "causou grande impressão e admiração a visita de $S$. Ex. a tão longínquo ponto da província. A população está animadíssima e vê na visita da primeira autoridade da província a este lugar, o indício de uma nova época de prosperidade para a importante comarca de Guarapuava". Noticiário/Telegramas (serviço especial da Gazeta). Gazeta Paranaense. Sexta-feira, 9 de abril de 1886. Ano X, n. 79, p. 02.

${ }^{22}$ Ver: Carta escrita a Luiz Daniel Cleve (jornalista, residente em Guarapuava), datada de 27 de novembro de 1895. Guarapuava/1928. op. cit., s/p.
}

${ }^{23}$ TAUNAY, op.cit., p. 430. 
As viagens de Taunay: natureza, civilização e governamentalidade na província ...

nete, de um centro urbano qualquer, para rememorar a viagem e dar a ela a corporeidade da palavra escrita, fixa no papel. O processo de significação era, portanto, em larga medida, posterior à experiência da viagem em si. De certa maneira, rememorar significava fazer uma nova viagem. Assim, o sentido da viagem se dá no entrecruzamento entre o caminho percorrido e sua rememoração. Trata-se de processos interdependentes, mas que caracterizavam uma experiência tipicamente moderna, que era, então, embrionária no Paraná. Assim, a insurgente necessidade de produzir conhecimentos a respeito do Paraná se materializava tanto na experiência in loco, do ver e experimentar a provincia, quanto em um processo reflexivo e de abstração.

Ainda no século XVIII, por exemplo, o naturalista francês Georges Cuvier propunha a superioridade da abstração e da reflexão na apreensão do mundo: "o viajante pode viajar apenas por uma estrada; é somente no gabinete que se pode vagar livremente através do universo"24. Gestava-se, assim, a premência de se ter controle sobre o meio advindo do conhecimento do seu funcionamento. Postando-se distante, alienado do mundo, numa atitude reflexiva, o homem seria capaz de organizá-lo, racionalizá-lo. Mesmo que tal postura seja um dos mais distintivos traços da modernidade, ela emergiu conjuntamente com a necessidade de conhecer o mundo, experimentá-lo. E é justamente isso que fez Alfredo Taunay quando presidente do Paraná: as viagens lhe davam não apenas uma intimidade com as questões pertinentes à provincia como lhe ajudavam a elaborar a melhor política para administrá-la.

Pode-se inferir ainda que a presença de Taunay no interior da provincia promoveria uma identificação dos moradores com o Paraná e o seu governo. Estabelecendo-se, assim, um processo no qual, ao conhecero território que governava, o presidente da Província conquistava reconhecimento por parte dos paranaenses. Dessa forma, ao ver ou ter conhecimento da presença do governante em sua localidade, os paranaenses sentir-se-iam pertencentes a uma realidade mais ampla, o $\mathrm{Pa}$ raná; reconhecer-se-iam como paranaenses por meio da visita

\footnotetext{
${ }^{24}$ CUVIER, Georges. Apud: MARTINS, Luciana de Lima. O Rio de Janeiro dos Viajantes: o olhar britânico. Rio de Janeiro: Jorge Zahar, 2001, p. 46.
} 
do presidente. Percebe-se, então, que, ao dar uma maior visibilidade a regiões do Paraná consideradas pouco desenvolvidas, Alfredo Taunay estava estabelecendo uma política de construção de uma territorialidade que implicava a constituição do próprio sentido da província.

A escrita era instrumento fundamental de tal construção, pois, por intermédio dela, um determinado Paraná ganhava existência. Um Paraná apontado para o futuro, muito embora, por vezes, a escrita de Taunay nos soe despretensiosa. Há que se considerar que, na medida em que Taunay registrava o interior da província, este ganhava materialidade. Além disso, os relatos facultavam que outras pessoas empreendessem viagens semelhantes, tornando as localidades do interior mais acessíveis e próximas. Considerando que a modernidade centraliza a produção de conhecimento - deslocando a centralidade da experiência -, mapas e registros descritivos de viagens elaborariam informações 'objetivas' a respeito dos espaços geográficos, facilitando que o mesmo percurso fosse realizado por qualquer um, que qualquer pessoa fizesse a mesma viagem futuramente. Não era mais a experiência que serviria como aval do conhecimento: cada vez mais, conhecer se daria de forma externa às vivências. Ou seja, com abstração, reflexão e a produção de certos aparatos garantir-se-iam a manutenção e a perpetuação das informações compiladas, tais como mapas, relatórios, livros, estatísticas.

\section{Formações rochosas, grutas e monges: percepções sobre os Campos Gerais}

Ao retornar de sua viagem a Guarapuava, Alfredo Taunay recebeu a indicação de um novo passeio pela província. Um amigo, percebendo como o presidente voltara entusiasmado de sua última viagem, incentiva-o a conhecer os Buracos, a Vila Velha e a Lagoa ${ }^{25}$, todos localizados nos Campos Gerais. Estando em final de governo, apenas realizou a tal viagem depois de deixar a presidência. Além das localidades recomendadas por Manuel

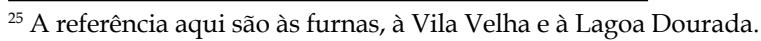


As viagens de Taunay: natureza, civilização e governamentalidade na província ...

Eufrásio Correia ${ }^{26}$, o amigo em questão, Taunay menciona, em seu relato de viagem, ter conhecido grutas e perfurações naturais, como a gruta Santa (também conhecida como gruta do Monge), a Capela do Tamanduá e o Campo do Buraco Grande ${ }^{27}$. Todas essas denominações são, evidentemente, populares: surgiram como iniciativa dos moradores locais. Salienta-se como essa lógica de nomeação se difere daquela que moveu Taunay a nomear acidentes geográficos no curso de suas viagens: esses ganharam nomes de figuras proeminentes da vida pública nacional e, sobretudo, da paranaense - Salto Visconde do Rio Branco, Bifurcação Lamenha Lins, Enseada Beaurepaire Rohan, Volta do Dr. Ermelino, Volta do Visconde de Guarapuava, Volta do Sertanejo Lopes, Volta do Barão de Antonina, entre outros.

A Vila Velha - um conjunto de formação rochosa, numericamente significativa, que a ação da erosão simula formas conhecidas da imaginação popular - impressionou Alfredo Taunay. De forma semelhante à gruta de Itaperuçu, as formações em terra pareciam iludir os olhos dos visitantes: "para quem a contempla de longe, semelha restos de alterosa fortaleza; de mais perto, porém, mostra aspecto de grande e abandonada cidade, com ruas bem retas, cortadas em esquadria e formadas de rochas aprumadas"28. Contudo, salienta-se que não lhe passa despercebido que as formações rochosas da Vila Velha tinham sua existência inscrita entre os habitantes locais, que reconheciam nelas torres, fortalezas, castelos ou catedrais ${ }^{29}$. E que eram eles, portanto, os primeiros a atribuir significados a tais formações: "[...] a imaginação popular imprime logo prestígio e significação e, não raro, da maior elevação poética"

De fato, os escritos de Taunay nos permitem entrever um pouco dos sentidos atribuídos por moradores dos Campos Gerais à localidade em que estão circunscritos. E isso não se restringe a Vila Velha. Assim, certas grutas - um tipo de

\footnotetext{
${ }^{26}$ Manoel Eufrásio Correia (1839-1888), natural de Paranaguá, bacharelou-se em Direito em São Paulo. No Paraná, dedicou-se à advocacia e envolveu-se na vida pública. Foi deputado provincial, presidente da Assembleia provincial, inspetor do Tesouro provincial, além de ter exercido cargos ligados ao judiciário, como juiz e promotor.

${ }^{27}$ Ver: TAUNAY, op.cit., p. 196-203.

${ }^{28}$ Ibidem, p. 200.

${ }^{29}$ Ibidem, p. 199.

${ }^{30}$ Ibidem.
} 
formação geológica bem característica dos Campos Gerais - estão relacionadas a histórias que envolviam monges milenaristas ou figuras tidas como milagreiras. Taunay visitou algumas dessas grutas, mas sua racionalidade não permitia que desse crédito a tais histórias: "não passavam, [...], de simples fanáticos, frades de origem duvidosa"31, dizia em referência aos monges. E juntava outros tantos adjetivos para desqualificar a experiência de tais homens - embusteiros, espertalhões, burlescos ${ }^{32}$-, figuras tidas como errantes e peripatéticas, que lhe pareciam estranhas, para não dizer ridículas ou cômicas.

Contudo, essas figuras eram respeitadas pelos habitantes dos Campos Gerais, que faziam das grutas locais de peregrinação $^{33}$. A população atribuía-lhes um sentido de sacralidade: a gruta Santa (ou gruta do Monge) ${ }^{34}$, por exemplo, atraía interesse e devoção especiais por se identificar nela uma pedra que, olhada a certa distância, se assemelhava à imagem de Sant'Anna. A gruta contava ainda com uma espécie de claraboia de dez metros de circunferência, responsável por trazer uma deslumbrante claridade a um ambiente tomado pela escuridão - tal abertura era chamada, pelos seus frequentadores, de portas do céu. Contribuindo com a magia do local, havia na gruta três pedras compridas que, quando tocadas por algum objeto metálico, produziam um som semelhante a um sino e outras pedras se assemelhariam a flores ou castiçais com velas ${ }^{35}$.

Constata-se, assim, a diferenciação de significados atribuídos às localidades paranaenses entre aqueles que lá vivem e um homem como Taunay - filho da civilização e guiado por olhos modernizadores. Ainda que não exponha um projeto para a região ou racionalize o seu futuro, Alfredo Taunay evidencia

\footnotetext{
${ }^{31}$ Ibidem, p. 202.

${ }^{32}$ Ibidem.

${ }^{33}$ Exemplo disso é a Gruta do Monge, localizada nas proximidades da cidade da Lapa. A respeito dela, Taunay afirma: "[...] lugar de romaria durante a Semana Santa dos moradores das circunvizinhanças, pois ali morou não pouco tempo, em 1842, como anacoreta um velho padre ou tido por tal, chamado Agostinho Maria". Ibidem, p. 206.

${ }^{34}$ A gruta também era chamada de gruta do Monge por já ter servido de morada a "um indivíduo que lia uma Bíblia velha e se dizia enviado de Deus". Idem, p. 202.

${ }^{35}$ Ibidem, p.203. Nesta gruta, as pedras não encarnavam apenas imagens religiosas: identificava-se uma que se assemelhava a uma capivara deitada de braços estendidos, outra que parecia uma estante de livros e ainda outra que parecia um púlpito.
} 
não compartilhar da mesma vivência e das mesmas crenças dos moradores dos Campos Gerais. Além disso, conferia ao seu relato dados relativos à localização, a medidas, a disposição interna das grutas, bem como a composição das rochas: informações, enfim, que remetem a uma cientificidade. Cientificidade esta, que se contrapunha ao caráter sagrado atribuído à natureza pelos populares ${ }^{36}$. Ainda que não se possa dizer que Alfredo Taunay fosse insensivel a um olhar poético para a vida e para a natureza, sua sensibilidade para o belo e para o poético fora constituída a partir de valores civilizacionais de modo que o belo e o artístico faziam sentido na medida em que estivessem a serviço do progresso da província.

Nesse contexto, os frequentadores das grutas eram tomados como supersticiosose os monges a elas vinculados tidos como pretensos milagreiros, fanáticos de origem duvidosa ${ }^{37}$. Tratava-se de indivíduos que não se adequavam ao ideal civilizatório e modernizador. De fato, a civilização e a modernidade implicavam combater crendicese superstições,romper com o passado e a tradição - elementos que marcavam a vida dos frequentadores das grutas dos Campos Gerais. Suas vidas e suas crenças estavam, dessa maneira, ligadas às histórias do lugar onde viviam de modo que passado e tradição reverberavam em seus cotidianos. As histórias dos monges que haviam passado ou vivido por ali, contadas e recontadas pelos mecanismos da oralidade, tinham funcionalidade no cotidiano de moradores locais. Eram histórias plausiveis naquele contexto e que nutriam a religiosidade e a fé popular. Nesse sentido, a própria geografia onde estavam inseridos reverberava sentidos na vida, ao mesmo tempo em que era significada a partir das suas experiências e percepções.

Assim, ao percorrer os mesmos caminhos e estarem presentes nas mesmas grutas que os monges estiveram, esses moradores marcavam suas ligações com a região, com a magiado lugar, afirmando seu vínculo ao passado e à tradição. Aqueles a que Alfredo Taunay refere-se como selvagens ou sertanejos estariam tão imiscuídos no meio em que viviam,

\footnotetext{
${ }^{36}$ A respeito do potencial da natureza em ser representada como sagrada, ver: SHAMA, op.cit.

${ }^{37}$ TAUNAY, op. cit., p. 201-202.
} 
que se confundiam com ele. De modo que viviam alheios ao valor estético das paisagens que os acolhia: "não thes merece a minima atenção, por fazerem dela [da paisagem] mais imediatamente parte"38. Estando Taunay preocupado com o futuro e em vislumbrar um projeto de província, comprometido com a racionalidade e a civilização, ele lida com a natureza, a vida e a verdade como elementos mensuráveis - diferenciando-se dos moradores dos Campos Gerais que, conforme depreende-se, as tratavam como desmesuráveis. Assim, sendo a razão e a consciência crítica agentes de expurgação do mundo das dimensões trágicas, loucas e cósmicas da vida, infere-se que qualquer projeto de modernidade interferiria nas tradições e no ritmo da localidade.

Enquanto a oralidade era um mecanismo de suporte das vivências populares, o meio pelo qual os habitantes dos Campos Geraisperpetuavam as suas experiências e conhecimentos, a escrita era essencial para significar as percepções de Taunay sobre o Paraná. Vale acrescentar que, na medida em que a escrita juntamente com as viagens pela provincia eram elementos fundamentais da prática de governar do presidente em questão, elas também participam do processo de significação do Paraná e da eleição dos lugares que lhe seriam mais representativos. Sendo assim, ainda que tenha recebido indicações de amigos para visitar determinados lugares ou que outros tenham sido determinados por necessidades politicas, Taunay demonstra ter um olhar em grande medida desarmado, no que concerne a hierarquizar a importância das localidades da província. Ele não parece ter apriori a noção do que deveria admirar na província, permitindo-se surpreender com a viagem. Para além de referências que ele tivesse sobre o Paraná - como o caso dos Buracos, da Lagoa e da Vila Velha - era ele mesmo que definia o que era relevante e digno de registro; que atribuía destaque a determinados lugares em detrimento de outros.

Assim, Taunay descreveu sua passagem por grutas e furnas dos Campos Gerais, discorreu sobre caminhos, quedas d'água, rios e lagoas, sem atribuir relevância especial a uma localidade por já considerá-la previamente significativa. Boa parte

\footnotetext{
${ }^{38}$ Ibidem, p. 200.
} 
dos lugares visitados e descritos pelo presidente não constituirão futuramente cartões postais ou serão tidos como de passagem obrigatória para quem desejasse conhecer o Paraná. Naqueles meados da década de 1880, o Paraná era uma incógnita em muitos aspectos: ainda não se sabia dizer ao certo o que o caracterizava, o que lhe era peculiar. Ainda não se tinha 'colado' a determinados lugares a ideia de que eram eminentemente paranaenses. De forma que, pensando-se nos escritos de Alfredo Taunay, verifica-se que a gruta de Itaperuçu ganhou maior relevância que a Vila Velha e a gruta do Monge lhe chamou mais atenção que as furnas. Isso porque, se a Vila Velha, por exemplo, ainda não havia se constituído como um sítio símbolo do Paraná, o olhar de Taunay poderia recair sobre ela sem lhe atribuir maiores importâncias. Mais do que isso, o que se sobressaîa ou não nas suas percepções se dava a partir das suas sensibilidades e experiências: em última instância, todos os lugares da provincia eram dignos de serem admirados e comentados.

\section{Natureza: beleza, encantamento e civilização}

"Mui rápida e penosa, mas interessantíssima, foi a excursão que fiz, como presidente da provincia do Paraná, até ao Porto de União da Vitória, no rio Iguaçu [...]"39. Com essas palavras, Alfredo Taunay inicia o relato de mais uma de suas viagens pelo Paraná. Essa experiência teve a particularidade de acontecer a bordo de uma embarcação a vapor - o vapor Cruzeiro - pertencente à companhia do Sr. Amazonas Marcondes. Tal embarcação fazia o percurso pelo rio Iguaçu três vezes por mês: para um trecho de cinquenta e cinco léguas e meia eram gastos dois dias para ir e quatro para voltar. Numa época em que as comunicações eram dificeis e demoradas, quando os rios eram, muitas vezes, utilizados como a única via de comunicação possivel entre as localidades, a empresa do Sr. Amazonas Marcondes representava, aos olhos de Taunay, significativo progresso para a provincia e uma oportunidade de melhor conhecê-la e ocupá-la. Assim, "[a empresa do Sr. Amazonas Marcondes] deu e dá progresso e vida social a muitíssimos pontos anteriormente desertos

${ }^{39}$ TAUNAY, op.cit., p. 215. 
e inóspitos dos nossos sertões, em que vagueiam ainda temidos $e$ indômitos bugres" $"$ E os elogios ao empreendimento não se esgotam por aí. O próprio Amazonas Marcondes, que acompanhou o presidente nessa viagem, é laureado de predicados por encarnar plenamente os valores de trabalho e civilização, tidos como incontestáveis para o bom futuro da provincia: "Itrata-se de] espirito ativo e empreendedor, que apresenta [...] trabalho e boa vontade nessa luta incessante entre as aspirações da civilização e a natureza bruta e selvática "1.

Haveria, assim, na natureza, algo de bruto e selvagem a ser controlado, bugres a serem domados, desertos e sertões a serem ocupados. Essa concepção filia Alfredo Taunay ao afã modernizador e civilizador característico do momento histórico em que ele vivia. Contudo, o anseio de ter a civilização chegando ao interior da província que administrava, convivia com sua capacidade de admirar, envolver-se e se surpreender com a natureza paranaense. Assim, ao descrever, por exemplo, uma queda d'água que conhecera quando estava a caminho de Guarapuava e que denominou Salto Visconde do Rio Branco, Taunay declara, após descansar, por cerca de uma hora, as vistas sobre a força das águas e a bela vegetação coberta de Aleluias: "[...] bem empregadas as canseiras a que nos haviamos sujeitado" 42 . Era o testemunho de que o que avistou compensou as dificuldades do caminho. Simon Schama nos ensina que, "antes de ser um repouso para os sentidos, a paisagem é obra da mente. Compõe-se tanto de camadas de lembranças quanto de estratos de rocha" ${ }^{\text {"3 }}$. Assim, sendo as paisagens frutos de uma dada dinâmica de olhar, salienta-se a predisposição de Taunay em recortar e poetizar fragmentos da natureza, tornando-os paisagens. Tal processo de constituição de paisagens era um acontecimento estético e político, por meio do qual o presidente da Província ia instituindo uma certa identidade ao Paraná.

\footnotetext{
${ }^{40}$ Ibidem, p. 223.

${ }^{41}$ Ibidem.

${ }^{42}$ Ibidem, p. 214.

${ }^{43}$ SCHAMA, op. cit., p. 17.
} 
As viagens de Taunay: natureza, civilização e governamentalidade na província ...

Caracteristicamente, Taunay percebe a natureza como plena e perfeita ${ }^{44}$, mas isso pode se manifestar de diferentes maneiras na sua escrita. Quando se refere ao Salto Visconde do Rio Branco, por exemplo,o presidente da Província atribui, em determinado momento, uma força quase humana à natureza: "a boca do precipicio, quando o rio galga o colossal obstáculo $[\ldots]^{\Re 45}$. Em outros se vale de termos próprios da engenharia $\mathrm{e}$ da arquitetura - tais como monólito, cornija, coluna ${ }^{46}$ - para descrever os cursos da queda d'água. E há outros em que trata as catadupas com uma linguagem poética e metafórica: assim, as águas cairiam formando crespos de ondulante cabeleira ${ }^{47}$ ou se desfaziam em nevoeiro, se pulverizando nos ares e desvendando nos raios do sol os ancenúbios do arco-íris ${ }^{48}$. Trata-se, portanto, de um olhar que não busca meramente reverter natureza em civilização, mas que se mostra sensivel a seu movimento e a suas formas.

Essa sensibilidade se manifesta, sobremaneira, ao aproximar a beleza da natureza paranaense a questões próprias da estética artística, não sendo, entretanto,isso perceptível apenas quando ele se utiliza de linguagem poética. Assim, a bordo do vapor Cruzeiro, Alfredo Taunay experimentava uma visão inédita do Paraná: "são lindíssimas as paisagens que se desenrolam nas apertadas curvas do rio [...]" ${ }^{\text {"9 }}$. Sob um novo ponto de vista, uma novaprovíncia se apresentava. O seu encantamento diante de tudo que vê é tamanho que as palavras lhe faltam e ele reconhece que a escrita não poderia ser capaz

\footnotetext{
${ }^{44}$ A respeito das formas harmônicas da natureza, Susan Buck-Morss, inspirada nos escritos de Walter Benjamin, propõe que o advento da técnica de ampliação fotográfica e a sua aplicação em fotografias de espécies vegetais proporcionou a percepção de que a natureza apresenta, muitas vezes, formas e harmonias de uma obra de arte. Assim, "Aqui há um uso da tecnologia não dirigido para o domínio da natureza, mas para levantar o 'véu' que nossa 'preguiça' arrojara sobre a velha natureza e que nos permite ver, na existência das plantas, 'um tesouro totalmente inesperado de analogias e formas'". Ver: BUCK-MORSS Susan. Velha Natureza/Nova Natureza. In: Dialética do Olhar: Walter Benjamin e o Projeto das Passagens. Belo Horizonte/Chapecó: UFMG/Argos, 2002. p. 191-199. Citação p. 195. [Grifo meu].

${ }^{45}$ TAUNAY, op. cit., p. 214.

${ }^{46}$ Ibidem.

${ }^{47}$ Ibidem, p. 213.

${ }^{48}$ Ibidem.

${ }^{49}$ Ibidem, p. 224.
} 
de fazer aquela descrição. Haveria uma espécie de descompasso entre o prazer experimentado em seu passeio pelo rio Iguaçu e o registro daquela experiência. As palavras não davam conta, não bastavam para traduzir o que as vistas experimentavam. Assim, ele confessa:

Uma coisa, de certo, ser-me-á de todo impossivel: transmitir ao leitor as múltiplas impressões que me saltearam o espírito, quando, aos olhos embelezados, ante mim se desdobrarão as formosas perspectivas do Iguaçu ${ }^{50}$.

Na tentativa de fazer o que ele mesmo julgara impossível, Taunay incorpora um conjunto de adjetivos a seu texto, no afã de qualificar a diversidade e a novidade que tanto o entusiasmava naquela viagem: ora tratava de imagens risonhas e amenas, ora de paisagens grandiosas e solenes ${ }^{51}$. E era justamente quando a natureza se mostrava grandedemais, aumentando a sensação de pequenez do homem diante do mundo, que Taunay deseja o pincel de um pintor para fazer aquilo que a sua pena não dava conta. Não era tarefa para a razão absorver e traduzir aqueles espetáculos da natureza: apenas a arte poderia dar conta dessa tarefa. Como se a pintura fosse uma arte menos comprometida com racionalidades e juízos humanos e, por isso, mais autorizada a representaras imagens que pululavam diante dos olhos ávidos do presidente da Província. Assim, no momento em que a embarcação já havia deixado para trás alguns afluentes do Iguaçu - como o Negrinho, o Negro, o Potinga e o Timbó - e se encontrava em um trecho em que as margens do rio distavam seiscentas braças uma da outra e poder-se-ia ver as imagens do céu azul e das árvores frondosas refletidas na superficie da água, o presidente se cala porque já não era capaz de transpor para palavras a emoção que tal beleza lhe despertava ${ }^{52}$.

Assim, a pintura, instrumento que Taunay julgou como o mais adequado para capturar o intangivel da natureza, constituía-se como lócus apropriado para produzir paisagens. De fato, pintura e paisagem são tão imbricadas que, de acordo com Maria Tereza Luchiari, foi na mediação com a arte que o

\footnotetext{
${ }^{50}$ Ibidem, p. 216.

${ }^{51}$ Ibidem.

${ }^{52}$ TAUNAY, op.cit., p. 216 
As viagens de Taunay: natureza, civilização e governamentalidade na província ...

lugar adquiriu o estatuto de paisagem ${ }^{53}$. Sendo assim, é preciso desnaturalizar as paisagens, posto que "é a cultura, a convenção e a cognição que formam esse desenho; que conferem a uma impressão retiniana a qualidade que experimentamos como beleza $^{\text {"54 }}$. Nesse sentido, sendo a paisagem um lócus da beleza por excelência, sua constituição, nas descrições de Taunay, corroboram para o alinhamento entre a estética e constituição de um sentido para o Paraná.

A percepção, testemunhada por Taunay na viagem pelo rio Iguaçu, de que as palavras não eram capazes de expressar a beleza e a grandeza da natureza paranaense, fez com que sentenciasse: "só nos enlevos da arte e na compreensão entusiástica do belo [se] pode conseguir fixar [...] as seduções e esplendores da grande obra da Criação"s5. De fato, a natureza e a arte se identificam por ambas serem geradoras, criadoras, por proverem vida e serem as duas fontes de onde emana a beleza ${ }^{56}$. " $A$ Arte é uma harmonia paralela à natureza ${ }^{\prime 57}$, sentenciou o pintor Paul Cézanne. Cada qual a sua maneira, arte e natureza carregam algo de vital para a existência e para a experiência humana. Talvez tenha sido justamente pelas identificações entre natureza e arte que Taunay atribui a esta última a capacidade de lidar com a magia, a beleza, o incontrolávele o arrebatadorque havia nas paisagens que contemplava a bordo do vapor Cruzeiro.

Viajar na embarcação do Sr. Amazonas Marcondes proporcionavaum ponto de vista privilegiado de percepção da província. Permitia contemplar algo inteiramente novo às vistas, na medida em que se chegava a regiões ainda intocadas pelo homem. Era o espetáculo da natureza que se apresentava àqueles que estavam a bordo do Cruzeiro:

E o vapor sulcou sereno e por dia esplêndido aquelas águas, por entre margens impolutas do machado, fazendo a cada momento

\footnotetext{
${ }^{53}$ LUCHIARI, Maria Tereza Duarte Paes. Apud: GIANNELLA, Letícia. Os diversos usos da paisagem ao longo do tempo na ciência geográfica. Geo UERJ, ano 10, v.2, n.18, $2^{\circ}$ semestre 2008, p. 67.

${ }^{54}$ SCHAMA, op.cit., p. 22.

${ }^{55}$ Ibidem.

${ }^{56}$ A respeito das relações entre natureza e arte, ver: OLIVEIRA, op.cit.

${ }^{57}$ Ibidem, p. 74.
} 
voar, ai sim, muita caça e aves aquáticas, rodeado enfim de todos os sinais de que jamais havia sido essa região explorada ${ }^{58}$.

Aliada a isso, a velocidade do vapor promovia uma aventura para os olhos, por meio da composição de imagens que se sucederiam rapidamente diante do viajante. De fato, com a proliferação dos inventos modernos (meios de transportes velozes, como trens e embarcações a vapor, a câmara fotográfica etc), o mundo não poderia ser visto, compreendido e experimentado como antes. Arte e técnica se fundiam contribuindo para uma percepção inédita do mundo, de forma que elementos como símbolo e utilidade, fantasia e função, arte e técnica tornaram-se inseparáveis e o mundo já não poderia ser absorvido fora dessas relações ${ }^{59}$. Sendo assim, a viagem no vapor Cruzeiro consistiu uma oportunidade para Taunay experimentar natureza e civilização, progresso e belezas naturais.

De dentro da embarcação, podia contar uma ampla variedade de plantas, cujo contraste de cores formava um cenário único: branquilhos, cambuins, acácias, gerivás, cedros, salgueiros, palmeiras, pinheiros e tantas outras ${ }^{60}$. Uma tal profusão de densidade e de cores de folhagens que o presidente da Província diz que seria capaz de dar apenas uma imperfeita e descora$d a$ noção de sua beleza ${ }^{61}$. Ressalta-se, contudo, que o pinheiro não ganhou lugar de destaque nessa descrição. A árvore que posteriormente se torna um dos mais distinguíveis símbolos do Paraná é avistada por Taunay, no entanto, seus olhos não lhe conferem maior ênfase que ao restante da vegetação. O pinheiro se confunde com outras árvores e plantas, ganhando apenas uma nota que expressava a sua abundância nas cercanias de Curitiba e no sertão de Guarapuava ${ }^{62}$. Contudo, nem mesmo a nota explicativa foi um privilégio seu: a maior parte das plantas citadas por Taunay ganhou semelhante nota. Dessa maneira,

\footnotetext{
${ }^{58}$ TAUNAY, op.cit., p. 233.

${ }^{59}$ Sobre essa questão, ver: BENJAMIN, Walter. A obra de arte na era da sua reprodutibilidade técnica. In: Arte e Técnica, Magia e Política: Ensaio sobre literatura e história da cultura (Obras Escolhidas, vol. I). 7 ed. São Paulo: Brasiliense, 1994. p.165-196. BUCK-MORSS, op.cit., p. 145-199.

${ }^{60}$ TAUNAY, op. cit., p. 224-225.

${ }^{61}$ Ibidem, p. 225.

${ }^{62}$ Ver: Ibidem.
} 
As viagens de Taunay: natureza, civilização e governamentalidade na província ...

o presidente nos dá a conhecer um Paraná cuja densidade e especificidades ainda estavam em grande medida por se construir, nos fazendo perceber como a imagem que se consolidou do Paraná no século XX não era inevitável - sendo apenas uma entre muitas possiveis.

\section{Govermentalidade: a constituição de uma política populacional na província}

Em suas viagens, Alfredo Taunay mostrou-se preocupado também com os caminhos e os núcleos populacionais pelos quais passava e em conhecer quem eram os habitantes do $\mathrm{Pa}$ raná. Afinal, precisaria estar atento às necessidades e potencialidades da provincia que administrava. Foi assim, por exemplo, que não lhe passaram despercebidas as condições das estradas por onde viajava, a exemplo da deterioração da estrada que levava à Palmeira ${ }^{63}$. Ou ainda, em outra ocasião, averiguou o andamento das obras de abertura da estrada para Palmas: visitou as barracas dos engenheiros; examinou os trabalhos técnicos; percorreu as picadas observando os declives e banhados que seriam contornados para a execução da estrada; compromete-se em providenciar, tão logo regressasse a Curitiba, um médico para permanecer junto às obras e atender os possiveis enfer$\operatorname{mos}^{64}$.

Aqui e ali podemos encontrar, nos escritos de Taunay em questão, marcas das preocupações de um presidente de Provincia. As responsabilidades administrativas guiavam seu olhar, afinal, cabia-lhe detectar os problemas, reverter os atrasos, pensar o futuro, prosperar a vida na província. Torná-la moderna requeria reflexão e planejamento, além de prover-lhe de atributos que fossem signos da civilização e do progresso. Assim, em sua passagem pela Câmara Municipal de Palmeira, pode admirar finissimas miniaturas representando paisagens e pessoas, feitas por um alemão chamado Virmond: "E tão notáveis

\footnotetext{
${ }^{63}$ TAUNAY, Alfredo d'Escragnolle. Pelos Verdes Campos. In: ABREU, Aluízio Ferreira de [Org.]. Campos e Pinheirais. Curitiba: Fundação Cultural (Coleção Farol do Saber), 1995, p. 128.

${ }^{64}$ TAUNAY, Alfredo d'Escragnolle. Curiosidades Naturais da Província do Paraná. op.cit., p. 236-237.
} 
são aquelas produções [- pondera Alfredo Taunay -] que fiz a ver a conveniência de enviá-las a Curitiba, onde figurariam com honra no Museu Paranaense"65. Escolas também eram instituições necessárias para se constituir uma província moderna. Desse modo, Taunay se diz satisfeito com a frequência de alunos que mantinha a escola pública masculina de São Luiz do Purunã ${ }^{66}$.

A respeito de São Luiz do Purunã, povoado nascente, o primeiro com o qual se deparava nos Campos Geraiso viajante vindo de Curitiba, Taunay menciona, entre várias outras coisas, que "a altitude geral e os ventos quase constantes impedem o desenvolvimento de moléstias endêmicas e febres intermitentes"67. A preocupação com a salubridade do meio não é algo que destoe das questões governamentais características daquele final de século. De fato, semelhante preocupação espelha um tipo de governamentalidade ${ }^{68}$ que privilegia "racionalizar os problemas propostos à prática governamental, pelos fenômenos próprios a um conjunto de seres vivos constituidos em população: saúde, higiene, natalidade, raças" assunção da vida pelo poder" - "uma tomada de poder sobre o homem enquanto ser vivo, uma espécie de estatização do biológico" ${ }^{\text {" }}$. Nesse contexto em que a população e a manutenção da vida ganham o centro da política de governo, a preocupação com o meio é investida em práticas como combater insalubridades e más condições de higiene, intervir nos focos de doenças, reverter os vazios.

No Paraná, as ações de Taunay que refletem a preocupação com a população materializam-se em situações como a referida percepção da boa circulação de ar de que gozava São Luiz do Purunã; a procura pelo rio mais propício para o abastecimento de água da capital - uma das mais graves questões de

${ }^{65}$ TAUNAY, Alfredo d'Escragnolle. Pelos Verdes Campos. op.cit., p. 129.

${ }^{66}$ TAUNAY, Alfredo d'Escragnolle. Curiosidades Naturais da Província do Paraná. op.cit., p. 217.

${ }^{67}$ TAUNAY, Alfredo d'Escragnolle. Pelos Verdes Campos. op.cit., p. 124.

${ }^{68}$ Terminologia/conceito retirado de Michel Foucault: FOUCAULT, Michel. A Governamentalidade. In: Microfísica do Poder. 13 ed. Rio de Janeiro: Graal, 1998, p. 277-293.

${ }^{69}$ FOUCAULT, Michel. Nascimento da Biopolítica. Resumo dos cursos do Collège de France (1870-1882). Rio de Janeiro: Jorge Zahar, 1997, p. 87-97.

${ }^{70}$ FOUCAULT, Michel. Aula de 17 de março de 1976. Em Defesa da Sociedade. São Paulo: Martins Fontes, 2002, p. 285-286. 
As viagens de Taunay: natureza, civilização e governamentalidade na província ...

Curitiba $^{71}$, nas palavras do presidente da Província. Ou ainda, o contrato do Sr. Conrado Buhres para o plantio de trigo na localidade do Portão ${ }^{72}$. Com efeito, a questão da produção de alimentos para o consumo dos paranaenses era problemática em uma província cuja produção de mate para exportação monopolizava todos os esforços. E nos núcleos urbanos - em especial Curitiba - o problema era especialmente sentido ${ }^{73}$. Nesse contexto, a imigração era cada vez mais solicitada como meio de diversificar as culturas e técnicas de produção, possibilitando alimentar os habitantes da provincia. Taunay, influenciado por Adolfo Lamenha Lins, que governara o Paraná uma década antes (de 8 de maio de 1875 a 16 de julho de 1877) incentivou os imigrantes a se instalarem nas proximidades de centros urbanos, acreditando que eles teriam melhores chances de prosperar e resolver os problemas relativos ao abastecimento alimentar da província.

O presidente da Província era verdadeiramente um entusiasta do processo imigratório. Como tantos de seus contemporâneos, ele via na colonização das terras brasileiras a grande chance de progresso nacional. Por isso, não é de se estranhar que durante o seu curto $^{74}$ governo, ele tenha se preocupado em organizar sociedadesdeimigração em localidades do interior, com o intuito de estimular o processo imigratório no Paraná ${ }^{75}$. Tais sociedades, além de se empenharem em incentivar o cultivo do solo, preocupavam-se em fazer o levantamento dos consertos

\footnotetext{
${ }^{71}$ TAUNAY, Alfredo d'Escragnolle. Pelos Verdes Campos. op.cit., p. 118.

72 TAUNAY, Alfredo d'Escragnolle. Curiosidades Naturais da Província do Paraná. op. cit.,. p. 221.

${ }^{73}$ Sobre a carestia de produção de alimentos para consumo interno da Província, ver: SANTOS, Carlos Roberto Antunes dos. História da alimentação no Paraná. 2 ed. Curitiba: Juruá, 2007.

${ }^{74}$ Vale ressaltar que a maioria dos presidentes de Província do Paraná exerceu o cargo por períodos pequenos, não excedendo a um ano, ou, quando muito, um ano e meio. Por essa razão, ao referir-se ao governo de Alfredo d'Esgragnolle Taunay como curto não se está propriamente comparando-o com os demais, mas ressaltando o breve tempo que ele teve para execução do que planejava. Acrescenta-se que, de acordo com a Constituição Brasileira de 1824, o cargo de presidente de Província era indicado pelo Imperador, levando em consideração os interesses e disputas partidárias (Partido Conservador e Partido Liberal). O presidente de Província não tinha um mandato, podendo ser desligado do cargo a qualquer momento.

${ }^{75}$ No governo de Taunay, foram inauguradas 11 sociedades de imigração: Paranaguá, Curitiba, Superagui (atual Guaraqueçaba), Porto de Cima, Morretes, Antonina, Campo Largo, Lapa, Ponta Grossa, Castro e Guarapuava.
} 
ou construções de pontes e estradas requeridas para agilizar as comunicações na província ${ }^{76}$.

Quando Taunay assumiu o governo do Paraná, esse já contava com alguns núcleos de imigrantes, para os quais não deixa de render elogios ${ }^{77}$. Contudo, a província contava também com um histórico de tentativas de colonização frustradas ${ }^{78}$. Daí a sua preocupação em fomentar uma política migratória bem alicerçada. Para tanto, teve por inspiração o governo de Adolfo Lamenha Lins, que estabelecera uma política de colonização bastante diversa do que era praticado até então: após visitar colônias fracassadas, Lamenha Lins estabelece novas diretrizes para a ocupação de terras por estrangeiros. Nada mais de colocar colonos em invios sertões, distantes de estradas e centros populacionais. A dificil realidade das condições de trabalho também deveria ser dita ao imigrante, evitando que vantajosas propagandas a respeito das facilidades e farturas tropicais o iludissem, fazendo-o desistir depois de instalado.

$\mathrm{O}$ investimento na imigração fora o principal eixo do governo de Lamenha Lins ${ }^{79}$. Observava-se, contudo, que a

\footnotetext{
${ }^{76}$ Sobre a política de imigração adotada por Alfredo Taunay, ver: Exposição com que o S. Ex. Sr. Dr. Alfredo d'Escragnolle passou a administração da Província do Paraná ao Ex. Sr. Dr. Joaquim de Almeida Farinha Sobrinho, $1^{\circ}$ vice-presidente a 3 de maio de 1886 . Curitiba: 48-70. [relatório de governo]

${ }_{77}$ Idem, p. 48-49.

${ }^{78}$ Dos casos frustrados de colonização de terras no Paraná, três ganharam maior ênfase nos relatos de Taunay: os casos da imigração francesa, russa e inglesa. A colônia Thereza, fundada pelo francês João Maurício Faivre, em 1847, nas margens do rio Ivaí (longe da capital e de qualquer núcleo populacional), era composta por homens e mulheres vindos dos arredores de Paris, portanto despreparados para a difícil vida no campo e para a atividade agrícola. O caso da imigração russa se deu após o governo Lamenha Lins, sendo uma espécie de retrocesso à política imigratória desse presidente. Em dezembro de 1878, chega ao Paraná a primeira leva de russos, num total de 1366 homens, dos 5000 previstos para entrarem na Província. O governo comprou terras de péssima qualidade para instalá-los e a preço muito maior do que valiam. Os russos não conseguiram produzir nessas terras e dezenas de famílias pediram repatriação. Já os colonos ingleses foram instalados em terras excelentes para a agricultura, no entanto, afastadas de estradas e centros consumidores. Ver: TAUNAY, Alfredo. Curiosidades Naturais da Província do Paraná. op.cit., p.218-221.

${ }^{79}$ A respeito de Lamenha Lins, Alfredo Taunay afirma: "É, sem dúvida alguma, um dos mais notáveis administradores que tem tido a província do Paraná a que prestou assinalados serviços, o mais relevante dos quais foi a organização de quase todos os belos centros imigrantistas, que circundam a cidade de Curitiba. Quando ele assumiu a presidência, a 8 de Maio de 1875, havia tão somente a colônia do Assungui e os núcleos Venâncio, Pilarzinho e Abranches, além de dois ou três no litoral e em pouco tempo criou mais oito ou dez que logo mostrarão o maior desenvolvimento. [...] Lamenha Lins deixou nome ainda hoje popularíssimo em toda aquela zona. Assim pudessem tais exemplos frutificar!". Ibidem, p. 226.
} 
As viagens de Taunay: natureza, civilização e governamentalidade na província ...

instalação de europeus de maneira desorganizada e sem prévios planejamentos, ao invés de aproveitar o potencial do estrangeiro, gerava frustrações e perdas de investimento. Com isso, Lamenha Lins inaugurava uma racionalização do processo de imigração na provincia e, principalmente, racionalizava a ocupação do território paranaense. Não bastava simplesmente trazer europeus para colonizar o Paraná, era preciso estudar o melhor lugar para instalá-los, pois, caso contrário, a experiência de imigração estaria fadada ao desastre. Por mais disciplinado que o imigrante fosse, de nada adiantaria seu esforço em produzir se não tivesse como escoar a produção e, para isso, era preciso estar perto de estradas. Lamenha Lins percebe que, devido às precariedades das vias de comunicação paranaenses, a melhor estratégia seria fundar colônias nas cercanias dos centros populacionais.

A política imigratória de Lamenha Lins deixou marcas no pensamento de Alfredo Taunay, assim: "para quem tem que viver do trabalho diário, muito mais vale um lote de terreno ruim e acanhado junto a uma cidade, do que opulentíssimas terras a cem léguas de qualquer centro de incitamento e socorro"80. Ao tentar colocar em prática as ideias de Adolfo Lamenha Lins, que haviam ficado esquecidas por quase uma década, Alfredo Taunay reconhecia que administrar uma província era um ato de planejamento. Daí, ele ter marcado seu governo com a preocupação em conhecer uma maior extensão de terras paranaenses: da mesma forma que Lamenha Lins, investira na imigração como meio de dar um novo perfil ao Paraná, empenhando-se em conhecer pessoalmente as experiências migratórias, a fim de não incorrer em erros.

Nesse sentido, ambos os presidentes de Provincia se aproximavam no caráter moderno que tentavam empreender em suas administrações. Um governo gerido pela lógica da modernidade pressupunha um planejamento racionalizado da utilização dos espaços paranaenses. A respeito da ocupação do Paraná pelo imigrante, Taunay sentencia: "Os nossos sertões e desertos só podem, só devem ser povoados - e hão de ser-por imigração europeia, que mui espontaneamente e por si caminhe da periferia para o centro, reflua do litoral e suas imediações para a zona

${ }^{80}$ Ibidem, p. 219. 


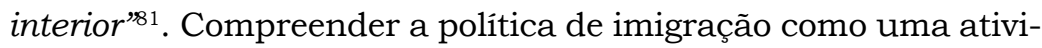
dade de organização territorial é, sem dúvida, uma forma de ter em conta o processo tipicamente moderno de minimizar as diferenças entre as regiões, trazendo-as para um mesmo patamar de organização e civilidade ${ }^{82}$. Mas, é também, de sobremaneira, uma forma de compreender a estruturação de uma maneira específica de governar que se constituía. De fato, conforme nos ensina Michel Foucault em A governamentalidade ${ }^{83}$, o problema da população instiga a constituição de uma arte de governar que rompe com as práticas soberanas que lhe antecedem.

Sendo assim, gerir uma população - questão que se esboçava para Taunay - levava a preocupações que escapavam a uma mera administração de território. A imigração forçava que se pensasse o homem em relação ao território (onde instalá-lo, os recursos de que usufruiria, as condições oferecidas pelo meio) e também em relação à riqueza que ele produziria. Há, portanto, um conjunto de coisas das quais o governo deve se ocupar quando centra sua ação na população. Assim, conforme Foucault:

Estas coisas, de que o governo deve se encarregar, são os homens, mas em suas relações com as coisas que são as riquezas, os recursos, os meios de subsistência, o território em suas fronteiras, com suas qualidades, clima, seca, fertilidade, etc; os homens em suas relações com outras coisas que são os costumes, os hábitos, as formas de gerir ou de pensar, etc.; finalmente, os homens em suas relações com outras coisas ainda que podem ser os acidentes ou as desgraças como a fome, a epidemia, a morte, etc ${ }^{84}$.

Inserindo-se nessa prática de governar, o presidente Taunay projeta uma província com base em inúmeras ações que se referem às estradas, ao abastecimento alimentar e de água, às condições de salubridade, de educação. Ressalta-se que a própria política de conhecer in loco as deficiências e potencialidades da província faz parte dessa governamentali-

\footnotetext{
${ }^{81}$ Ibidem, p. 219-220.

${ }^{82}$ Sobre esta questão, ver: CORRÊA, Roberto Lobato. Espaço, um conceito-chave da geografia. In: CASTRO, Iná Elias de [et al]. Geografia: Conceitos e Temas. 3 ed. Rio de Janeiro: Bertrand Brasil, 2001, p. 35.

${ }^{83}$ FOUCAULT, Michel. A Governamentalidade. op.cit.

${ }^{84}$ Ibidem, p. 282.
} 
As viagens de Taunay: natureza, civilização e governamentalidade na província ...

dade. O imigrante seria decisivo nesse processo, por isso Taunay confere-lhe tamanha visibilidade. Refletia sobre as experiências de colonização e de políticas colonizadoras na província, mas também se mostrava atento aos imigrantes que encontrava em suas viagens, identificando-os em seus predicados e em suas origens étnicas. Assim, refere-se à beleza do caminho ladeado de habitações de poloneses e italianos; elogia o casal de italianos que já possuía uma vistosacasa de vivenda, graças ao trabalho árduo de carregar e vender lenha e mil serviços feitos na cidade; menciona a satisfação de trabalhar do italiano que guiava o veículo que lhe conduzia a Palmeira; percebe que, logo à saída de Curitiba, um inglês chamado Whiters havia montado um estabelecimento de preparo de carnes frias, responsável por excelentes linguas salgadas ${ }^{85}$.

Para Alfredo Taunay, a marca distintiva do imigrante seria, certamente, sua disposição para o trabalho. Olhava, assim, com grande simpatia para aqueles que prosperavam graças a seu próprio esforço, ao seu trabalho e registrava o exito dos empreendimentos que davam certo: "o edificio, por enquanto mais importante de todo o local [São Luiz do Purunã], é a casa de negócio, aliás bem sortida, anexa ao decente hotelzinho, do Sr. Boutin, e pertencente ao mesmo senhor's6. A exemplo do Sr. Boutin, aqueles que prosperavam economicamente eram identificados pelo nome, ganhando espaço e predicados na pena do presidente da Província. Nesse sentido, refere-se ao capitalista Manoel Ricardo dos Santos, familiarmente conhecido como Dodoca, dono de um bem montado estabelecimento de socar mate: "Homem estimável e sério, fizera fortuna em Morretes, serra abaixo, e afinal se estabelecera na capital, onde possuía uma das mais confortáveis e luxuosas habitações"87. A disciplina, a seriedade e a valorização ao trabalho contrastar-se-iam, no entanto, com a postura do brasileiro:

$\mathrm{O}$ estrangeiro que viaja pela nossa principal artéria de comunicação, fica na verdade impressionado e pasmo ao contemplar os verdadeiros desertos que ela vai atravessando e se de vez em quando descobre alguma casinha, é uma palhoça, um rancho

\footnotetext{
${ }_{85}^{85}$ TAUNAY, Alfredo d'Escragnolle. Pelos Verdes Campos. op. cit., p. 117.

${ }^{86}$ Ibidem, p. 120.

${ }^{87}$ Ibidem, p. 118.
} 
mais ou menos em ruínas, desequilibrado, todo furado, aberto aos quatro ventos, e debaixo do qual se abrigam a malandrice e a indolência; mulheres desgrenhadas a fumarem cigarrinhos o dia inteiro, homens deitados em esteiras, ou espichados em redes a arranharem a viola, criancinhas cobertas de farrapos ou de todo nuas, com ventres intumescidos, um terreiro mais ou menos sujo, defronte da choupana, cães e porcos em quantidade mas muito magros, algumas galinhas a cacarejarem por ali, tudo à espera da pequena porção de milho que foi plantada em dias de menos preguiça ou dos cachos de banana que ainda não ficaram de vez, isto é, que não começaram a amadurecer para logo serem $\operatorname{comidos}^{88}$.

O nacional era, portanto, representado como o avesso do estrangeiro. Taunay parece avistá-lo sempre ao longe, sua descrição é sempre imprecisa: alguém sem rosto, sem nome, sem profissão, entregue à ignorância, à indolência, ao vício e às doenças. Caracterizava, assim, um cenário que de todo desabonava a ideia do Paraná que idealizava e que se materializaria com a imigração: "o contraste ai é doloroso [e acentuado] para o coração patriota"89, sentenciava Taunay ao contrapor a moradia e a disposição ao trabalho do europeu com as do brasileiro. Agregado à desqualificação do caipira, delineava-se à afirmação de um vazio territorial que se configurava com o uso de termos como sertões ou desertos, marcando a invisibilidade daqueles que viviam no interior paranaense. De fato, a ideia de vazio tinha funcionalidade como tática discursiva, fortalecendo as afirmações ligadas à imigração - afinal, se havia espaços vazios, eles poderiam ser ocupados sem questionamentos e sem conflitos.

Nesse contexto, restava às vidas infames ${ }^{90}$ apresentarem-se como flashes, como lócus descontínuos nos escritos de Alfredo Taunay: caipiras, caboclos, bugres eram denominações imprecisas que circunscreviam determinados sujeitos que lhe desagradava. Aqueles são mencionados apenas quando são percebidos como problema, quando se mostravam como empecilho ao projeto de governo. Dessa forma, há em seus escritos lacunas de silêncio a respeito dos indígenas - o que

\footnotetext{
${ }^{88}$ Ibidem, p. 121.

${ }^{89}$ Ibidem.

${ }^{90}$ Tomo o termo vidas infames emprestado de Michel Foucault. Ver: FOUCAULT, Michel. A vida dos infames. In: O que é um leitor? Lisboa: Passagens, 1992.
} 
As viagens de Taunay: natureza, civilização e governamentalidade na província ...

ilumina o questionamento a respeito de termos como desertos ou sertões: afinal como poder-se-ia usá-los se a presença indígenas fosse condignamente referenciada? Assim, o indígena era mencionado quando se tornava uma ameaça à vida fora do seu agrupamento. Em passagem por uma localidade denominada de Chapéu do Sol, por exemplo, Taunay observa: "Mora ali essa pobre gente em um recanto da zona de vagabundagem $e$ correrias de indômitos bugres, a cujos assaltos estão sujeitos"1. E prossegue mencionando que o pai e o marido de uma rapariga que lá vivia haviam sido mortos a flechadas, no ano anterior ${ }^{92}$. Estar em condição de ser visto, nesse contexto, implicava, portanto, os interesses e projetos que guiavam o "nós" civilizador que o presidente da Província representava.

A legitimidade de habitar o Paraná era construída por intermédio de um tipo de discursividade que descredenciava certos sujeitos para que outros fossem positivados. Nesse sentido, as identidades dos grupos que habitavam o Paraná são indissociáveis. Trata-se de "territórios sobrepostos, histórias entrelaçadas" "93, para nos valermos da expressão de Edward Said. Imigrantes (devidamente distinguidos em sua origem étnica), caipiras ou caboclos (denominações utilizadas para referir-se aos que não tinha origem étnica definida, invariavelmente pobres) e os indigenas compunham um jogo de identificações binárias. Assim, os dois últimos identificar-se-iam pela inaptidão ao trabalho: "E a propósito do calor exagerado, ai vem para índios $e$ caipiras a sesta indefinida e que liga dias e dias seguidos" e, em contraparte, completa: "os filhos da Europa apenas se lhes entrega um canto de terra, estão a ele presos nos múltiplos misteres do seu amanho e cultivo de sol a sol!"'94.

Nesse âmbito, a civilizaçãoera um valor incontestável, identificando-se com predicados como a educação dos espíritos, a polidez, a cultura das artes e da ciência, o crescimento do comércio e da indústria, as comodidades materiais ${ }^{95}$. Tornando-

${ }^{91}$ TAUNAY, Alfredo d'Escragnolle. Curiosidades Naturais da Província do Paraná. op.cit., p. 231.

${ }^{92}$ Ibidem.

${ }^{93}$ Ver: SAID, Edward W. Cultura e Imperalismo. São Paulo: Companhia das Letras, 1995.

${ }^{94}$ TAUNAY, Alfredo d'Escragnolle. Pelos Verdes Campos. op.cit., p. 123.

${ }^{95}$ STAROBINSKI, Jean. As máscaras da civilização: ensaios. São Paulo: Cia das Letras, 2001, p. 14. 
-se critério por excelência, a civilizaçãojustificará todo o tipo de desqualificação daquele que lhe é alheio: "tudo que não é civilização, tudo que lhe resiste, tudo que a ameaça, fará figura de monstro ou de mal absoluto' ${ }^{196}$. A ordem que institui e contrapõe os grupos humanos no Paraná é tributária desse quadro que coloca em oposição civilizadose incivilizados, encarando-os como noções inseparáveis. Nessa perspectiva, é necessário que haja aqueles que não correspondam ao ideal desejado, que sejam o avesso da civilizaçãopara que os civilizados existam. Operando esse jogo de oposições, o presidente Taunay constituía o paranaense desejável, em diálogo com uma dada modernidade que se insinuava na política da provincia.

Resumo: Alfredo d'Escragnole Taunay foi presidente do Paraná por sete meses, entre 1885 e 1886, instaurando uma política governamental marcada por deslocamentos pelo interior da província. Nessas viagens, pode conhecer tanto povoações quanto lugares onde a natureza era dominante, além de pessoas de diversas condições sociais e origens étnicas. Neste artigo, abordam-se as percepções de Taunay sobre o Paraná, sua prática de registrar por escrito suas experiências de viagem, além da própria prática de viajar.

Palavras-chave: Viagem. Natureza. Civilização.Paraná.

Abstract: Alfredo d'Escragnole Taunay was the president of Paraná for seven months, between 1885 and 1886. He has established a government policy marked by shifts in the interior of the province. On these trips, he had the opportunity to visit both villages and places where nature was dominant, as well as people from several ethnic origins and social conditions. This article expounds on Taunay's perceptions about Paraná, his practice of writing down his travel experiences, along with the very practice of traveling.

Keywords: Travel. Nature. Civilization. Paraná.

Artigo recebido para publicação em 16/06/2012

Artigo aprovado para publicação em 15/10/2012

${ }^{96}$ Ibidem, p. 33. 